\title{
Host preference of the egg parasitoids Telenomus remus and Trichogramma pretiosum in laboratory
}

\author{
Maria Mirmes Paiva Goulart ${ }^{1}$, Adeney de Freitas Bueno ${ }^{2}$, \\ Regiane Cristina Oliveira de Freitas Bueno ${ }^{3} \&$ Adenil Ferreira Diniz ${ }^{4}$
}

\author{
${ }^{1}$ Universidade de Rio Verde 75901-970 Rio Verde-GO, Brasil. mirmes@uol.com.br \\ ${ }^{2}$ Embrapa Soja, Rodovia Carlos João Strass, s/n, Caixa Postal 231, 86001-970 Londrina-PR, Brasil. adeney@cnpso.embrapa.br \\ Author for correspondence. \\ ${ }^{3}$ Universidade de Rio Verde, 75901-970 Rio Verde-GO, Brasil. regianecrisoliveira@gmail.com \\ ${ }^{4}$ Universidade Estadual de Goiás, Rua 7, s/n, Setor Sul, 76190-000 Palmeiras de Goiás-GO, Brasil.
}

\begin{abstract}
Host preference of the egg parasitoids Telenomus remus and Trichogramma pretiosum in laboratory. This research aimed to evaluate the host preference of the egg parasitoids Telenomus remus and Trichogramma pretiosum. Trials were carried out in laboratory, under controlled environmental conditions $\left(25 \pm 2^{\circ} \mathrm{C}\right.$ temperature; $70 \pm 10 \% \mathrm{RH}$; and $14 \mathrm{~h}$ photophase). The parasitoid searching behavior was evaluated based on the distribution (\%) of eggs parasitized by each parasitoid, on egg masses of each host species. Results showed the host preference of T. remus by Spodoptera cosmioides eggs. T. pretiosum, reared in A. gemmatalis eggs, choose to parasitize always eggs of the host where the parasitoid had been reared. The egg preference was not observed when T. pretiosum was reared in S. frugiperda eggs. These results show that, in general, host preference of $T$. remus is less influenced by the host where it is developed than T. pretiosum. Host preference is an important parameter for biological control programs because more than one pest species may occur in the field, different from those where they were reared in the laboratory.
\end{abstract}

KEYWORDS. Anticarsia gemmatalis; Anagasta kuehniella; biological control; Spodoptera spp.

RESUMO. Preferência hospedeira dos parasitoides de ovos Telenomus remus e Trichogramma pretiosum em laboratório. Este trabalho objetivou avaliar a preferência hospedeira dos parasitóides de ovos Telenomus remus e Trichogramma pretiosum. Os experimentos foram conduzidos em laboratório, sob condições controladas (temperatura de $25 \pm 2^{\circ} \mathrm{C}$; umidade relativa de $70 \pm 10 \%$; e fotofase de 14 horas). O comportamento de busca dos parasitóides foi avaliado através da distribuição (\%) de ovos parasitados por espécie de parasitóide, em massas de ovos de cada hospedeiro na combinação estudada. Os resultados mostraram que T. remus preferiu parasitar ovos de $S$. cosmioides. T. pretiosum, criados em ovos de A. gemmatalis, preferiu parasitar sempre os ovos dos hospedeiros nos quais foram multiplicados. Essa preferência não foi observada quando $T$. pretiosum foi multiplicado em ovos de $S$. frugiperda. Esses resultados mostram que, em geral, a preferência hospedeira de T. remus é menos influenciada em relação a $T$. pretiosum pelo hospedeiro em que o parasitóide se desenvolveu. A preferência hospedeira é um importante parâmetro a ser considerado em programas de controle biológico porque em condições de campo mais de uma espécie praga pode estar presente, diferente daquela em que foi criado em laboratório.

PALAVRAS-CHAVE. Anticarsia gemmatalis; Anagasta kuehniella; controle biológico; Spodoptera spp.

Chemical control is the most commonly used technique against insect-pests; however, as a result of the intensive use of insecticides, a series of negative impacts on the environment may occur. The incorrect use of chemicals can, besides turning insect management inefficient, cause outbreaks of secondary pests, selection of resistant insects, and ecological imbalances, for example (Nakano 1986). Thus, the adoption of efficient and low environmental impacting tactics is fundamental for the success of pest control based on the Integrated Pest Management (IPM). One of the most promising tactics is the biological control by releasing egg parasitoids (Parra et al. 1987).

Among the egg parasitoids, several species in the genus Trichogramma (Hymenoptera, Trichogrammatidae) have been widely used, because they are easily reared on alternative host (Parra 1997; Haji et al. 1998). They are efficient parasitoids, mainly on eggs of Lepidoptera (Botelho1997).
Releases of Trichogramma species for biological control of insect pests have been performed over a hundred years, reaching, nowadays, an area of approximately 16 million hectares, although, some authors refer to 32 million hectares of Trichogramma spp. releases (Parra \& Zucchi 2004).

Inundatory releases have been used mainly for controlling insect pests in crops such as corn, sugarcane, tomatoes, rice, cotton, sugar beet, apple, prune, vegetables, and forests (Hassan et al. 1998; Parra et al. 2002). Moreover, studies have demonstrated that Trichogramma pretiosum Riley, 1879 (Hymenoptera, Trichogrammatidae) can be used to control Anticarsia gemmatalis Hübner, 1818 (Lepidoptera, Noctuidae) and Pseudoplusia includens Walker, 1857 (Lepidoptera, Noctuidae) on soybean (Bueno et al. 2009). However, despite the parasitism potential of $T$. pretiosum and other species of this genus, they are inefficient in parasitizing eggs laid in overlapping layers, as the egg masses of Spodoptera 
frugiperda J. E. Smith, 1797 (Lepidoptera, Noctuidae) and Spodoptera cosmioides Walker, 1858 (Lepidoptera, Noctuidae). These commonly infesting corn pest species have been recorded injuring soybeans, especially $S$. cosmioides (Bueno et al. 2007).

Another egg parasitoid, Telenomus remus Nixon, 1937 (Hymenoptera, Scelionidae), has been observed parasitizing eggs of five different species of Spodoptera, even on overlapping layer egg masses (Bueno et al. 2008). Each female of $T$. remus produces about 270 eggs during its reproductive lifespan (Morales et al. 2000). This parasitoid has been released in corn field areas, as part of IPM programs, in Venezuela, where the parasitism rates reached up to $90 \%$ (Ferrer 2001), demonstrating the high potential of this control agent of several species of Spodoptera.

Despite the great potential in using egg parasitoids as biological control agents, the success or failure of field releases of these insects depends, basically, on the knowledge of the bioecological characteristics of the parasitoids and of their interactions with the target host (Bourchier \& Smith 1996). It is important to consider that when the parasitoid is released in the field, it will probably have a larger host choice than in the laboratory. This host diversity may influence the capacity of the parasitoid in finding the target host. Another important point to be considered is the quality of the insect reared under laboratory conditions. In general, an easy-reared alternative host is normally used for mass production. However, the successive rearing on alternative hosts may affect the host preference of the natural enemy, by altering the control efficiency against the target (Cobert 1985). T. pretiosum is commonly reared on eggs of the alternative host Anagasta kuehniella Zeller, 1879 (Lepidoptera, Pyralidae), which is not a target pest in the field. Thus, if the parasitoid searching behavior changes when moved from the alternative host to the target species, the control efficiency may decrease (Cobert 1985). Therefore, the objective of this research was to evaluate the host preference of two egg parasitoids, T. remus and T. pretiosum, after being reared on eggs of different hosts.

\section{MATERIAL AND METHODS}

The tests were performed in the laboratory, under controlled environmental conditions $\left(25 \pm 2^{\circ} \mathrm{C}\right.$ temperature; $70 \pm 10 \% \mathrm{RH}$; and $14 \mathrm{~h}$ photophase), in a completely randomized experimental design, with two treatments and 12 replications for each bioassay, aiming to evaluate $T$. pretiosum and T. remus host preference for eggs of different hosts. The adults of T. remus were reared on eggs of $S$. frugiperda for several generations. The adults of T. pretiosum were divided in two groups: in the first, the parasitoids were multiplied - after several generations in eggs of the factitious host A. kuehniella-for one generation, in eggs of $S$. frugiperda; in the second group, the multiplication was in eggs of $A$. gemmatalis. For all bioassays, the host eggs were kept under the same environmental conditions.

T. remus multiplication was carried out in a small white cardboard containing $30 \mathrm{~S}$. frugiperda egg masses with about
100 eggs each. The $24 \mathrm{~h}$ old eggs were glued on the cardboards and introduced into transparent circular plastic containers $(20 \mathrm{~cm} \times 10 \mathrm{~cm})$ with $T$. remus adult females. A droplet of honey was used for adult parasitoid feeding. After $24 \mathrm{~h}$ parasitism, the cardboard cards were individualized into plastic containers, as previously described, but without the parasitoid. These containers were sealed with a plastic wrap. After about 10 days, the parasitoids emerged and the females were collected to be used in the experiments. The multiplication of T. pretiosum followed the same procedure used for $T$. remus rearing, but the hosts were $A$. gemmatalis eggs or $S$. frugiperda egg masses.

The tests on host preference were carried out in arenas with dual-choice chance, as proposed by Thuler et al. (2007). Each arena was composed by four transparent polyethylene vials, measuring $4 \mathrm{~cm}$ tall $\times 2 \mathrm{~cm}$ in diameter, with four plastic micro-tubes $(1.5 \mathrm{ml})$. These micro-tubes containing a card with approximately 20 eggs of each host and were equidistantly disposed, forming an " $\mathrm{X}$ " in the arena. A fifth tube was vertically placed in the center of the arena, where a single female was placed for each replicate. The eggs were exposed to parasitism for $24 \mathrm{~h}$ period, and then the females were removed. The eggs were observed daily until the emergence of parasitoids. The number of parasitized eggs was recorded daily.

In the assays performed with $T$. remus, the host comparisons were: 1) $S$. frugiperda x $S$. cosmioides; 2) $S$. frugiperda $\mathrm{x}$ Spodoptera albula (Walker) (Lepidoptera: Noctuidae), and 3) S. cosmioides x S. albula. In the bioassays carried out with T. pretiosum, the host comparisons for the parasitoids reared on eggs of $S$. frugiperda were: 1) $S$. cosmioides x $A$. kuehniella; 2) S. frugiperda x A. gemmatalis; 3) S. frugiperda x A. kuehniella; and 4) S. frugiperda x S. eridania. Finally, for the parasitoids reared on eggs of $A$. gemmatalis, the comparisons were: 1) $S$. frugiperda x A. gemmatalis and 2) A. gemmatalis x A. kuehniella.

The number of eggs parasitized was evaluated and the parasitism distribution (\%) was calculated by dividing the number of parasitized eggs of each species by the total of parasitized eggs of the replication. Results were submitted to exploratory analyses for checking the assumptions of residual normality, the homogeneity of variance of treatments to perform analysis of variance (ANOVA). The means were compared by $\mathrm{F}$ test $(\mathrm{P} \leqslant 0,05)$ for statistical significance.

\section{RESULTS AND DISCUSSION}

Females of T. remus evaluated in the choice test for eggs of Spodoptera preferred the eggs of $S$. cosmioides. In the comparison between $S$. frugiperda and $S$. cosmioides, 74\% of the parasitized eggs were from $S$. cosmioides (Fig. 1A). The preference for parasitizing $S$. cosmioides eggs was also observed when compared with $S$. albula (Fig. 1B). Differently, T. remus did not show significant statistical differences in the preference of eggs of S. frugiperda and S. albula (Fig. 1C). 


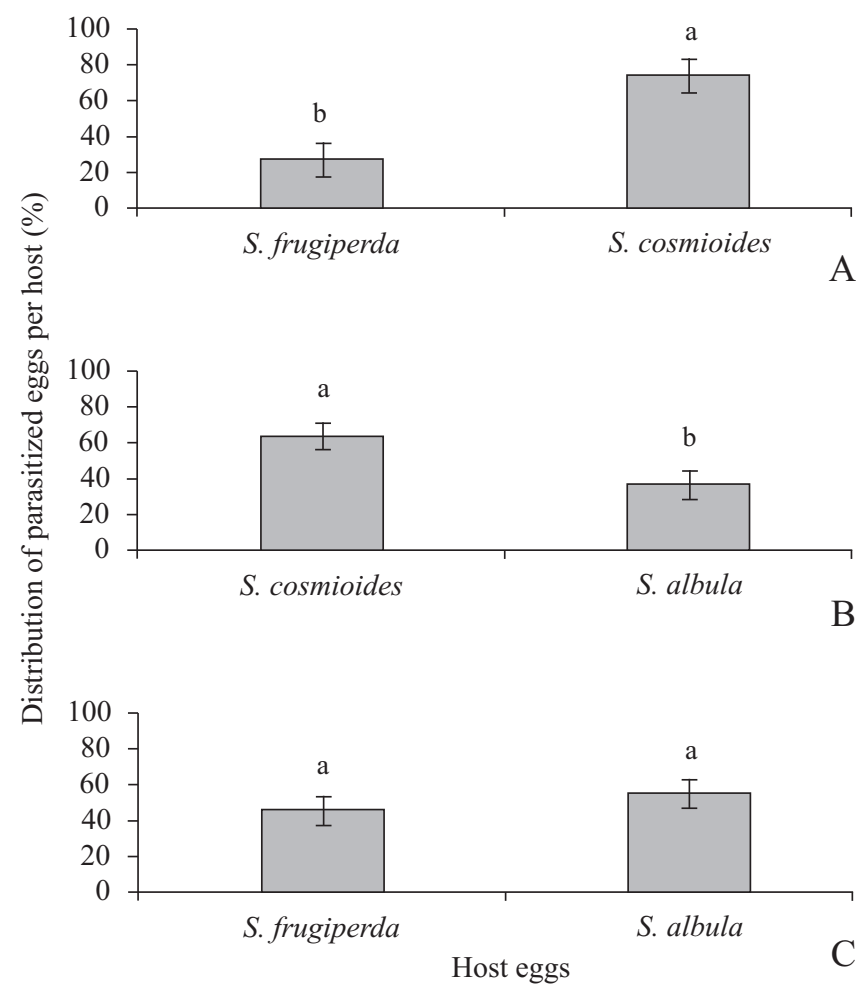

Fig. 1. Distribution (\%) of eggs parasitized by Telenomus remus (Mean \pm $\mathrm{SE}$ ) on egg masses of different hosts of the genus Spodoptera in double choice tests, after that parasitoid was reared in eggs of Spodoptera frugiperda for several generations. Means followed by the same letter are not statistically different from each other by $\mathrm{F}$ test, at $5 \%$ probability.

T. remus females were reared in $S$ frugiperda eggs for several generations. Thus, the non-preference of the parasitoid for the eggs of $S$. frugiperda demonstrates that the host acceptance or preference behavior of the parasitoid females cannot be attributed to the pre-imaginal conditioning, previously described by Cobert (1985) and Kaiser et al. (1989). This parasitoid preference can not be also attributed to associative learning, or $\alpha$-conditioning. In this case, females associate new stimuli (acquired) to the innate ones, and are able to adapt themselves to the environment they have lived, as adults or juveniles (Kaiser et al. 1989; Vinson 1998; Nurindah et al. 1999). These results indicate that T. remus can be maintained in laboratory cultures for several generations in eggs of a single host species without reducing the parasitism efficiency for other target pests in the field.

It is important to consider that $S$. cosmioides is becoming a key pest in soybean crops in recent years (Bueno et al. 2007). As indicated by the results, $S$. cosmioides is a preferential host for T. remus, demonstrating its potential as biocontrol agent against this specie in Soybean-IPM. Further studies, however, are necessary to establish a biological control program using this parasitoid in soybean fields. Moreover, $S$. cosmioides does not display the cannibal habit observed for $S$. frugiperda. Thus, $S$. cosmioides larvae can be reared in laboratory without individualization, a condition that is essential for $S$. frugiperda rearing. Therefore, the mass rearing of $S$. cosmioides may be less laborious and less expensive as compared to $S$. frugiperda, and thus more economically feasible. This is a favorable characteristic for using $S$. cosmioides for massal rearing of $T$. remus in the laboratory because costs can be reduced.

Additionally, T. remus is described in the literature as an excellent egg parasitoid for the Spodoptera complex and perfectly feasible in integrated management programs for $S$. frugiperda (Figueiredo et al. 1999). It is important to consider that not only $S$. cosmioides, but also other species of the Spodoptera complex have increased their importance on crops such as soybean, corn and cotton. Another noticeable issue is that $T$. remus can effectively parasitize the inner layers of the egg masses (Cruz \& Figueiredo 1994), whereas the parasitoids from the Trichogramma genus are able to parasitize only the outer layers (Beserra et al. 2002). Therefore, T. remus can be considered as an efficient biocontrol agent of $S$. frugiperda eggs (Johnson 1984), as well as of the other species of Spodoptera that lay eggs in layered clusters, such as $S$. cosmioides.

When one generation of T. pretiosum is reared in eggs of $S$. frugiperda, females preferred $S$. frugiperda eggs ( $100 \%$ of the parasitized eggs) instead S. eridania (Fig. 2A). However, in the dual-choice parasitism test, there were no statistically significant differences between treatments using eggs of $S$. frugiperda and $A$. gemmatalis as well as eggs of $S$. frugiperda and A. kuehniella (Figs. 2B, 2C). Probably, this means that even if the parasitoid was reared for one generation in eggs of $S$. frugiperda, this was not the preferential host for parasitism. T. pretiosum also did not show any preference between eggs of S. cosmioides and A. kuehniella (Fig. 2D).

Females of $T$. pretiosum, reared for one generation in eggs of $A$. gemmatalis, preferred the eggs of $A$. gemmatalis instead of $S$. frugiperda and A. kuehniella eggs for parasitism (Figs. 3A, 3B). Differently, results obtained with parasitoids reared in eggs of $S$. frugiperda suggest that the host in which the insect was reared is actually important. Nevertheless, host selection cannot be explained simply in relation to the host in which the parasitoid was multiplied. The host preference of females of the genus Trichogramma presents a complex relation with the nutritional quality of the hosts chosen for parasitism and is also related to the host in which the parasitoid was multiplied, as previously observed by Molina et al. (2005) and Volpe et al. (2006).

Characteristics of the host egg include differences in the surfaces, size and structure of the chorion, and changes in color during embryonic development, as well as in size and egg volume. All these peculiarities, which are specific to each host egg, can influence not only the time necessary for Trichogramma spp. exploratory behavior, but also the development of the parasitoid in the specific host (Cônsoli et al. 1999). Therefore, differences of the host in which the parasitoid developed also influence the preference of the female parasitoid in choosing eggs of the same host used for its development.

The parasitism potential of T. remus and T. pretiosum could be confirmed in our study and their use in biological control 


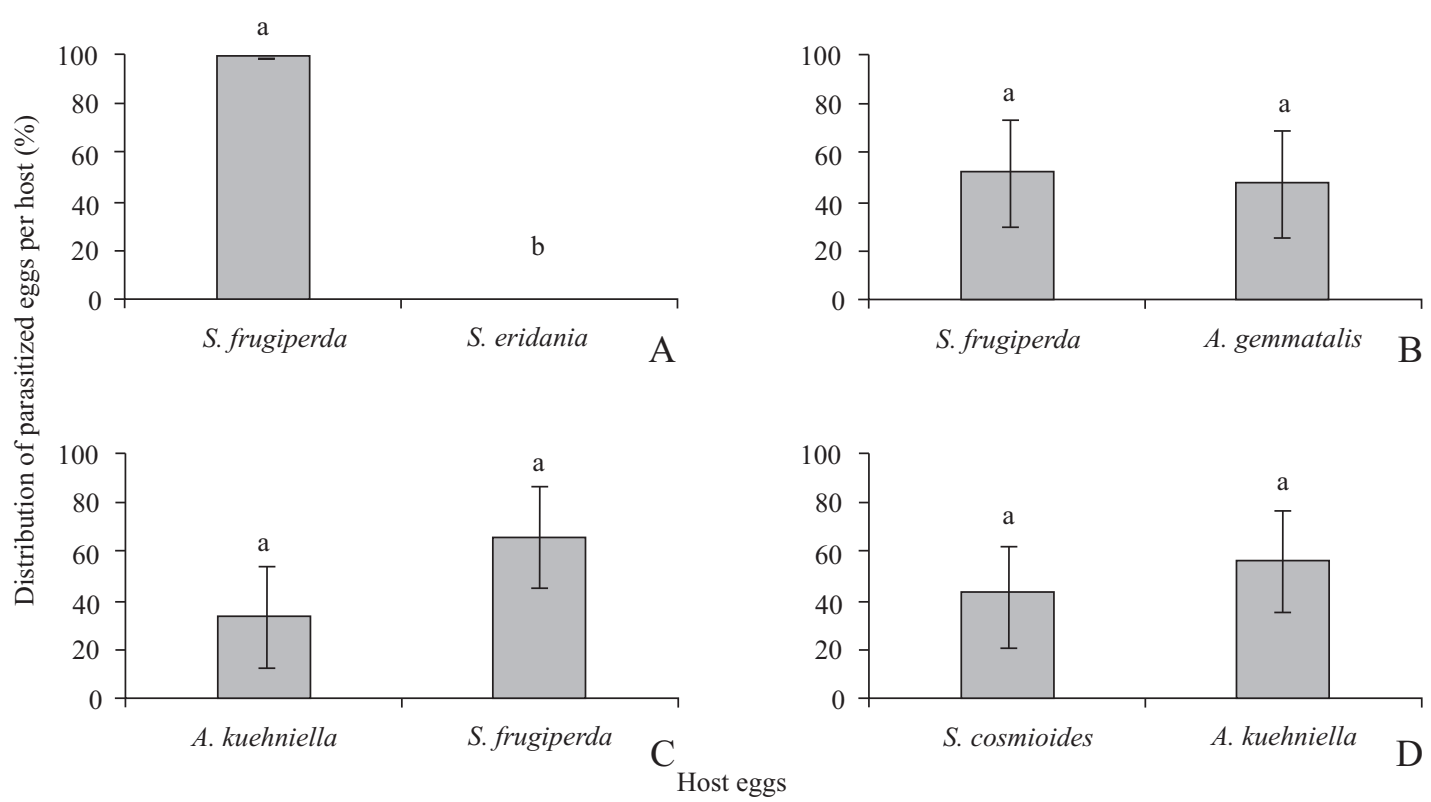

Fig. 2. Distribution (\%) of eggs parasitize by Trichogramma pretiosum (Mean \pm SE) on egg masses of different hosts, in double choice tests, after that parasitoid was reared for one generation in eggs of Spodoptera frugiperda. Means followed by the same letter are not statistically different from each other by $\mathrm{F}$ test, at $5 \%$ probability.

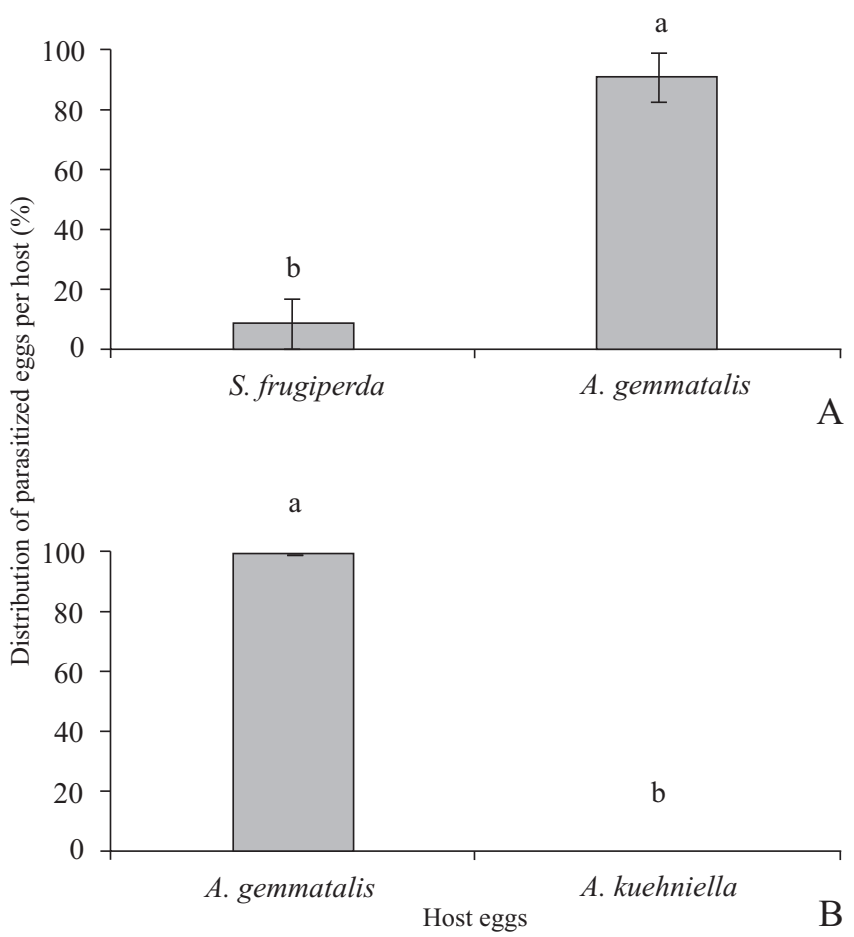

Fig. 3. Distribution (\%) of eggs parasitized by Trichogramma pretiosum $($ Mean $\pm \mathrm{SE}$ ) on egg masses of different hosts, in double choice tests, after that parasitoide was reared for one generation in eggs of Anticarsia gemmatalis. Means followed by the same letter are not statistically different from each other by $\mathrm{F}$ test, at $5 \%$ probability.

programs can be recommended. Further field studies related to biology and parasitism capacity of $T$. remus and $T$. pretiosum in eggs of different species of the genus Spodoptera and other pests are needed.

\section{CONCLUSIONS}

The parasitoid Telenomus remus prefers to parasitize eggs of Spodoptera cosmioides instead of eggs of $S$. frugiperda in laboratory conditions. Trichogramma pretiosum, reared in $A$. gemmatalis eggs, prefers to parasitize eggs of the host where the parasitoid had been reared. Egg preference does not occur when $T$. pretiosum is reared in S. frugiperda eggs. In general, host preference of T. remus is less influenced by the host where it has developed than T. pretiosum. For both parasitoids, host preference is an important parameter to be studied since it might influence parasitism mainly in the field where several pest species may occur.

\section{ACKNOWLEDGMENTS}

Thanks are expressed to C.B. Hoffmann-Campo for reviewing the manuscript and to Embrapa Soja and CAPES (process 23038.035744/2008-89) for the financial support making this research possible. This paper was approved for publication by the Editorial Board of Embrapa Soja as manuscript number $5 / 2010$.

\section{REFERENCES}

Beserra, E. B; C. T. S. Dias \& J. R. P. Parra. 2002. Distribution and natural parasitism of Spodoptera Frugiperda (Lepidoptera, Noctuidae) eggs at different phenological stages of corn. Florida Entomologist 85: 588-593.

Botelho, P.S.M. 1997. Eficiência de Trichogramma em campo, p. 303-318. In: J. R. P. Parra \& R. A. Zucchi (ed.). Trichogramma e o controle biológico aplicado. Piracicaba, FEALQ, 287 p.

Bourchier, R. S. \& S. M. Smith. 1996. Influence of environmental conditions and parasitoid quality on field performance of Trichogramma minutum. Entomologia Experimentalis et Applicata 80: 461-468. 
Bueno, R. C. O. F; J. R. P. Parra; A. F. Bueno; F. Moscardi; J. R. G. Oliveira \& M. F. Camillo. 2007. Sem barreira. Revista Cultivar 93: 12-15.

Bueno, R. C. O. F.; T. R. Carneiro; D. Pratissolli; A. R. Bueno \& O. A. Fernandes. 2008. Biology and thermal requirements of Telenomus remus reared on fall armyworm Spodoptera frugiperda eggs. Ciência Rural 38: 16

Bueno, R. C. O. F.; J. R. P. Parra; A. F. Bueno \& M. L. Haddad. 2009. Desempenho de tricogramatídeos como potenciais agentes de controle de Pseudoplusia includens Walker (Lepidoptera, Noctuidae). Neotropical Entomology 38: 389-394.

Cobert, S. A. 1985. Insect chemosensory responses: a chemical legacy hypothesis. Ecological Entomology 10: 143-153.

Cruz, I. \& M. L. C. Figueiredo. 1994. Estudos preliminares do parasitóide Telenomus remus Nixon sobre ovos de Spodoptera frugiperda. Relatório Téenico Anual do Centro Nacional de Pesquisa de Milho e Sorgo 1992-1993 6: 104-106.

Cônsoli, F. L.; E. W. Kitajima \& J. R. P. Parra. 1999. Ultrastructure of the natural and factitious host eggs of Trichogramma galloi Zucchi and Trichogramma pretiosum Riley (Hymenoptera, Trichogrammatidae). International Journal of Insect Morphology and Embryology 28: 211-229.

Ferrer, F. 2001. Biological control of agricultural insect pest in Venezuela; advances, achievements, and future perspectives. Biocontrol News and Information 22: 67-74

Figueiredo, M. L. C.; I. Cruz \& T. M. C. D. Lucia. 1999. Controle integrado de Spodoptera frugiperda (Smith \& Abbot) utilizando-se o parasitóide Telenomus remus Nixon. Pesquisa Agropecuária Brasileira 34: 1975-1982.

Haji, F. N. D.; J. Velasquez; E. Bleicher; J. A. Alencar; A. T. Haji \& R. S. Diniz. 1998. Tecnologia de produção massal de Trichogramma spp. Petrolina, Embrapa-CPATSA, 24 p.

Hassan, S. A.; E. Kolher \& W. M. Rost. 1998. Mass production and utilization of Trichogramma: Control of the codling, Cydia pomonella and the summer fruit tortrix moth Adoxophyes orana (Lepidoptera, Tortricidae). Entomophaga 33: 413-420.

Kaiser, L.; M. H. Pham-Delegue \& C. Masson. 1989. Behavioral study of plasticity in host preferences or Trichogramma maidis (Hymenoptera, Trichogrammatidae). Physiological Entomology 14: 53-60.

Johnson, N.F. 1984. Systematics of Nearctic Telenomus: classification and revisions of the Podisi and Phymatae species groups
(Hymenoptera, Scelionidae) Knull. series 2. Columbs, Ohio State University, $113 \mathrm{p}$.

Molina, R. M. S.; V. Fronza \& J. R. P. Parra. 2005. Seleção de Trichogramma spp., para o controle de Ecdytolopha aurantiana, com base na biologia e exigências térmicas. Revista Brasileira de Entomologia 49: 152-158.

Morales, J.; J. S. Gallardo; C. Vásquez; Y. Rios. 2000. Patrón de emergência, longevidad, parasitismo y proporción sexual de Telenomus remus (Hymenoptera, Scelionidae) com relación al cogollero del maíz. Instituto de Biotecnologia Aplicada à Agropecuária 12: 47-54.

Nakano, O. 1986. Avanços na prática do controle de pragas. Informe Agropecuário 12: 55-59.

Nurindah; B.; W. Cribb \& G. Gordh. 1999. Experience acquisition by Trichogramma australicum Girault (Hymenoptera, Trichogrammatidae). Australian Journal of Entomology 38: 115-119.

Parra, J. R. P. 1997. Técnicas de criação de Anagasta kuehniella, hospedeiro alternativo para produção de Trichogramma, p. 121-150. In: J. R. P Parra \& R. A. Zucchi. (ed.). Trichogramma e o controle biológico aplicado. Piracicaba, FEALQ, $287 \mathrm{p}$.

Parra, J. R. P. \& R. A. Zucchi. 2004. Trichogramma in Brazil: feasibility of use after twenty years of research. Neotropical Entomology 33: 271-281.

Parra, J. R. P.; R. A. Zucchi \& S. Silveira Neto. 1987. Biological control of pests through egg parasitoids of the genera Trichogramma and/or Trichogrammatoidea. Memórias do Instituto Oswaldo Cruz 82: 153 160 .

Parra, J. R. P.; P. S. M. Botelho; B. S. Corrêa-Ferreira \& J. M. S. Bento. 2002. Controle biológico uma visão inter e multidisciplinar. p. 125142. In: J. R. P. Parra; P. S. M. Botelho; B. S. Corrêa-Ferreira \& J. M. S. Bento. (ed.) Controle biológico no Brasil: parasitóides e predadores. São Paulo: Manole, 609 p.

Thuler R. T.; H. X. L. Volpe; S. A. Bortoli; R. M. Goulart \& C. L. T. P. Viana. 2007. Metodologia para avaliação da preferência hospedeira de parasitóides do gênero Trichogramma Westood. Boletín de Sanidad Vegetal. Plagas 33: 333-340.

Vinson, S. B. 1998. The general host selection behavior of parasitoid Hymenoptera and a comparison of initial strategies utilized by larvaphagous and oophagous species. Biological Control 11: 79-96.

Volpe, H. X. L.; S. A. De Bortoli; R. T. Thuler; C. L. T. P. Viana \& R. M. Goulart. 2006. Avaliação de características biológicas de Trichogramma pretiosum Riley (Hymenoptera, Trichogrammatidae) criado em três hospedeiros. Arquivos do Instituto Biológico 73: 311315. 